\title{
Cloning and Expression of a Gene for Resistance to Butirosin both in Escherichia coli and Bacillus subtilis
}

\author{
Takayuki Hoshino, ${ }^{*}$ Takeshi UozUmi** and Teruhiko BEPPU \\ Department of Agricultural Chemistry, The University of Tokyo, \\ Bunkyo-ku, Tokyo 113, Japan
}

Received April 26, 1983

\begin{abstract}
We have cloned a butirosin resistance gene located on a $2.9 \mathrm{Md} H$ indIII fragment of the chromosomal DNA of Bacillus vitellinus Z-1159, a butirosin producer, on a shuttle vector, pTA1302 (5.2 Md, $\left.\mathrm{Ap}^{\mathrm{r}}, \mathrm{Cm}^{\mathrm{r}}\right)$. The recombinant plasmid conferred resistances to butirosin, neomycin and kanamycin, on both Escherichia coli and Bacillus subtilis. Functional expression of aminoglycoside- $3^{\prime}$-phosphotransferase activity from the butirosin resistance gene was confirmed in the cell extracts of both $E$. coli and $B$. subtilis harboring the recombinant plasmid. A cleavage map of the recombinant plasmid was constructed.
\end{abstract}

Recently, molecular cloning experiments and construction of host-vector systems of Bacillus subtilis have been widely performed. $^{1 \sim 4)}$ We also constructed a host-vector system of $B$. subtilis ${ }^{5}$ ) and some shuttle vectors useful for molecular cloning experiments both on Escherichia coli and B. subtilis. In this paper, we report the cloning of a DNA fragment encoding resistance to butirosin and other aminoglycoside antibiotics, derived from the chromosome of butirosin-producing microorganism $B$. vitellinus, using a shuttle vector, pTA1302, as a cloning vehicle. The utility of our shuttle vector, pTA1302, was confirmed by the present work.

\section{MATERIALS AND METHODS}

Bacterial strains and plasmids. Butirosin-producing microorganism $B$. vitellinus Z-1159 was kindly supplied by Takeda Chemical Industries, Ltd. (Osaka, Japan). E. coli $\mathrm{C} 600 \mathrm{r}^{-1} \mathrm{~m}^{-}\left(\right.$leu $^{-}$, thr $^{-}$, thi $\left.{ }^{-}\right)$and B. subtilis RM125 $(h s r M, h \operatorname{sim} M, \arg 15, l e u)^{6)}$ were used as recipient strains for cloning experiments. The shuttle vector, pTA1302, used in this experiment was constructed in our laboratory. This plasmid is a recombinant plasmid of pBR322 and
pTP4. ${ }^{7)}$ The scheme of construction and a physical map of this plasmid are shown in Fig. 1.

Media and transformation procedures. All bacteria were grown in NY medium. ${ }^{6)}$ Competent cells of $E$. coli $\mathrm{C} 600 \mathrm{r}^{-} \mathrm{m}^{-}$were prepared by the method of Horinouchi et $a l .{ }^{8)}$ After transformation, cultures were incubated at $37^{\circ} \mathrm{C}$ for $90 \mathrm{~min}$, and then plated onto NY agar containing $\mathrm{Cm}$ $(10 \mu \mathrm{g} / \mathrm{ml})$, Ap $(50 \mu \mathrm{g} / \mathrm{ml})$ and Bt $(10 \mu \mathrm{g} / \mathrm{ml})$. Transformation of $B$. subtilis protoplasts was performed according to the method of Chang and Cohen. ${ }^{9)}$ After expression for $90 \mathrm{~min}$, protoplasts were plated on DM3 regeneration medium containing $\mathrm{Cm}(20 \mu \mathrm{g} / \mathrm{ml})$ and $\mathrm{Bt}$ $(50 \mu \mathrm{g} / \mathrm{ml})$.

Isolation of DNAs. Chromosomal DNA of B. vitellinus Z-1159 was isolated by the method of Saito and Miura. ${ }^{10)}$ Plasmid DNAs were isolated from B. subtilis as previously described. ${ }^{11)}$ Plasmid DNAs in $E$. coli were prepared according to Horinouchi et al. ${ }^{8)}$ Large scale preparation of plasmid DNAs was performed by $\mathrm{CsCl}$-ethidium bromide density gradient centrifugation.

Restriction endonuclease digestion and ligation. Restriction endonucleases EcoRI and HindIII were purchased from Boehringer Mannheim. Digested DNAs were analyzed by agarose gel electrophoresis $(0.7 \%$ agarose [Seakem]). T4 DNA ligase was purchased from Boehringer. Ligation procedures were performed accord-

* Present address: Fermentation Research Institute, Tsukuba 305, Japan.

** Offprint requests to: T. Uozumi.

Abbreviations: $\mathrm{Cm}, \mathrm{Tc}$ and $\mathrm{Bt}$ : chloramphenicol, tetracycline and butirosin, respectively. Resistances to these antibiotics are expressed as $\mathrm{Cm}^{\mathrm{r}}, \mathrm{Tc}^{\mathrm{r}}$ and $\mathrm{Bt}^{\mathrm{r}}$, respectively. $\mathrm{Md}$ : megadaltons. 


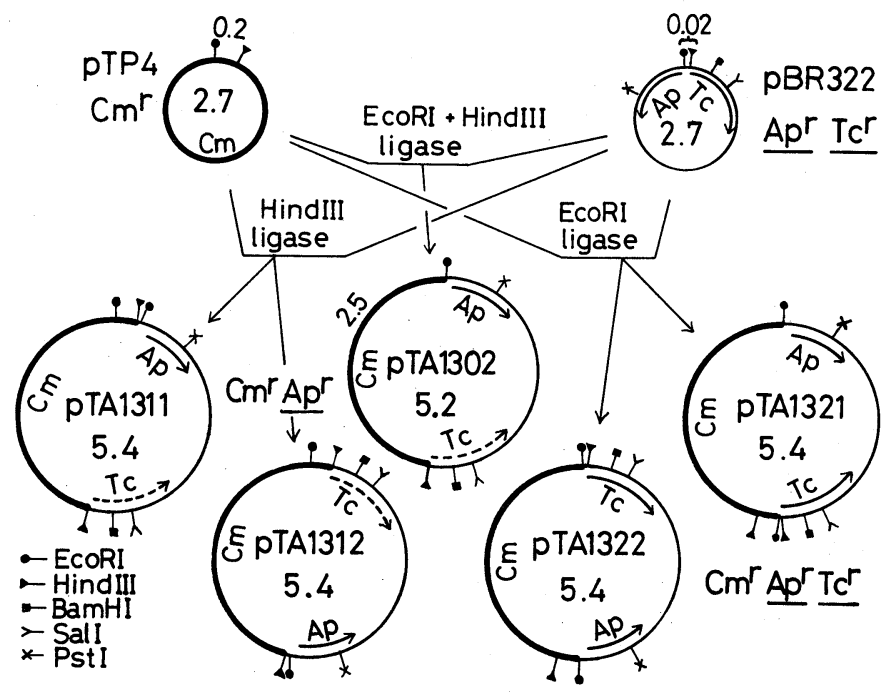

FIG. 1. Schematic Presentation of Construction of Shuttle Vectors.

In this figure, we describe five recombinant plasmids. Recombinant plasmids between pTP4 and pBR322 were constructed by the HindIII and/or EcoRI-ligase methods in E. coli. These plasmids were all useful in E. coli as vectors. But in $B$. subtilis, although plasmids pTA1302, pTA1311, pTA1321 and pTA1322 were stable, pTA1312 was not stably maintained. In this case, some deleted plasmids were recovered from the host (unpublished data). This instability did not depend on the recE4 gene in the host cell. (B. subtilis RM141 (a $r e c \mathrm{E} 4$ derivative of $B$. subtilis RM125) was used as recipient strain in this experiment.)

In this study, we used pTA1302 as a cloning vehicle, because this plasmid has single Eco RI and HindIII sites, respectively. Underlined antibiotic resistance in this figure indicates that this resistance is not expressed in $B$. subtilis.

ing to the supplier's recommendations.

Hybridization procedures. Three micrograms of chromosomal DNA of $B$. vitellinus Z-1159 was digested with EcoRI and HindIII respectively and electrophoresed on a $0.7 \%$ agarose slab gel in TBE buffer $(50 \mathrm{~mm}$ Tris-borate ( $\mathrm{pH} 8.3$ ), 1 mм EDTA). Blotting of DNA fragments from alkali-denatured agarose gel onto a nitrocellulose membrane (S \& S Co.) was carried out with an electroblotting system (Wakamori Co.) in TAE buffer ( $40 \mathrm{~mm}$ Tris-acetate $(\mathrm{pH} 7.8), 20 \mathrm{~mm}$ sodium acetate, $1 \mathrm{~mm}$ EDTA) at 0.2 to $0.5 \mathrm{~A}$ for 2 to $3 \mathrm{hr}$. DNA fragments were fixed to the membrane in a vacuum oven at $80^{\circ} \mathrm{C}$ for $2 \mathrm{hr}$.

Labelling of the recombinant plasmids was performed with a nick translation kit (Amersham) using ${ }^{32} \mathrm{P}-\mathrm{dCTP}$ (Amersham) according to the supplier's recommendations. Hybridization was performed as follows. DNAfixed nitrocellulose filters were preincubated in $5 \mathrm{ml}$ of modified Denhardt's solution $(5 \times \mathrm{SSC}$ containing $0.1 \%$ $(\mathrm{w} / \mathrm{v})$ of bovine serum albumin, ficoll, polyvinylpyrollidone and SDS, and $50 \mu \mathrm{g} / \mathrm{ml}$ of sonicated calf thymus DNA) at $62^{\circ} \mathrm{C}$ for 16 to $18 \mathrm{hr} .3 \mathrm{ml}$ of ${ }^{32} \mathrm{P}$-labeled plasmid DNA solution in modified Denhardt's solution (approximately $5 \times 10^{6} \mathrm{dpm}$ of probe per $2 \times 11 \mathrm{~cm}$ filter) was added to the preincubation mixture and incubation was continued for an additional 16 to $18 \mathrm{hr}$ at $62^{\circ} \mathrm{C}$. After washing with $2 \times \mathrm{SSC}$ containing $0.1 \% \mathrm{SDS}$, filters were dried at room temperature. Exposure to Kodak XAR-5 Xray film was done with an intensifying screen (Dupont, Lightning Plus) at room temperature.

Assay of aminoglycoside-3'-phosphotransferase activity. Preparation of cell free extracts from $B$. vitellinus, $E$. coli and $B$. subtilis, and assaying of aminoglycoside-3'phosphotransferase activities were performed as previously described. ${ }^{12)}$ The antibiotic butirosin was kindly supplied by Takeda Chemical Industries, Ltd. (Osaka). Kanamycin B and tobramycin (3'-deoxy-kanamycin B) were gifts from Meiji Seika, Ltd. (Kawasaki, Japan).

\section{RESULTS}

Cloning of DNA fragments encoding resistance to butirosin in E. coli

Three micrograms of $B$. vitellinus chromosomal DNA was partially digested with HindIII and mixed with $1 \mu \mathrm{g}$ of HindIIIdigested pTA1302. T4 DNA ligase (1 unit) was 
added to the mixture $(100 \mu \mathrm{l})$ which was then incubated at $22^{\circ} \mathrm{C}$ for $1 \mathrm{hr}$. The ligated DNA was transformed into $0.5 \mathrm{ml}$ of competent cells of E. coli $\mathrm{C} 600 \mathrm{r}^{-} \mathrm{m}^{-}$. After expression in $\mathrm{NY}$ medium at $37^{\circ} \mathrm{C}$ for $90 \mathrm{~min}$, cultures were plated onto NY agar containing Ap (50 $\mu \mathrm{g} / \mathrm{ml}), \mathrm{Cm}(10 \mu \mathrm{g} / \mathrm{ml})$ and $\mathrm{Bt}(10 \mu \mathrm{g} / \mathrm{ml})$, and 11 transformants were isolated. Plasmid DNAs were prepared from these transformants, and their molecular sizes and cleavage patterns were investigated with EcoRI and HindIII. The eleven recombinant plasmids were classified into 4 types, pTABR4, pTABR5, pTABR6 and pTABR10 by the sizes of insertion fragments. Cleavage patterns of these plasmids are shown in Fig. 2 and cleavage maps are summarized in Fig. 3. All the four recombinant plasmids contained, on the vector plasmid pTA1302, a HindIII fragment $(4.6 \mathrm{Md})$ in common, which was derived from

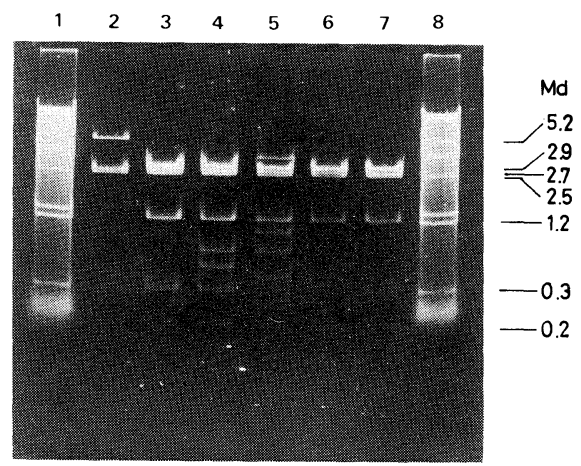

Fig. 2. Cleavage Patterns of pTABR4, pTABR5, pTABR6 and pTABR 10 .

1 and 8, lambda DNA fragments digested with HindIII; 2, EcoRI-digested pTA1302 and EcoRI plus HindIII digested pTA1302 were mixed. Other columns were $E c o$ RI plus HindIII digested DNAs. 3 and 6, pTABR4; 4, pTABR5; 5, pTABR6; 7, pTABR10. Agarose gel electrophoresis was carried out on $0.7 \%$ agarose slab gel.
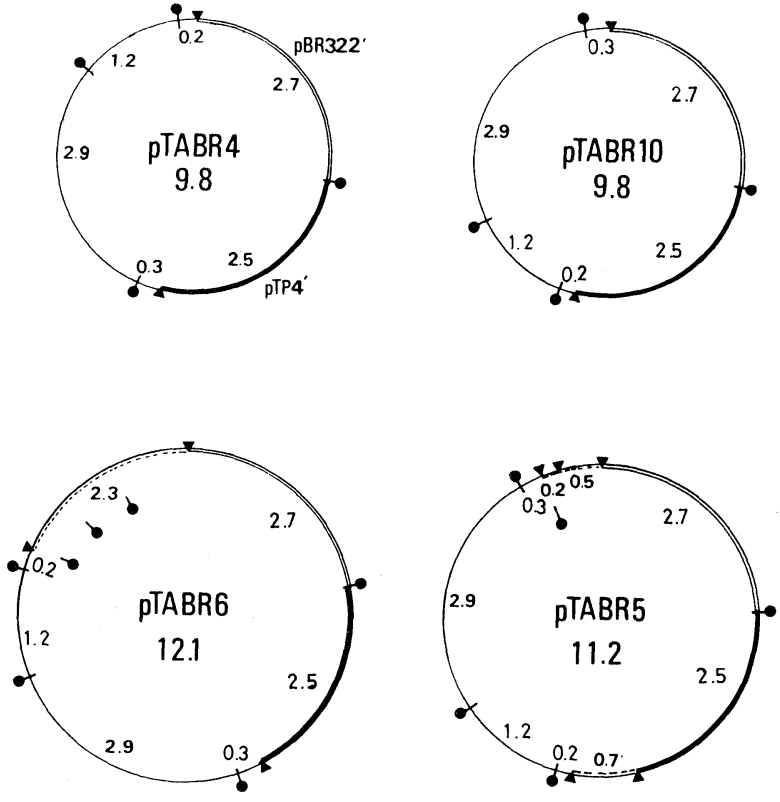

- Ecori site

- HindIII site

PTP4 '

pBR322,

$4.6 \mathrm{md}$ fragment of B.vitellinus encoding

resistance to butirosin.

another fragment of B.vitellinus

FIG. 3. Cleavage Maps of pTABR4, pTABR5, pTABR6 and pTABR10 (size in megadaltons). 


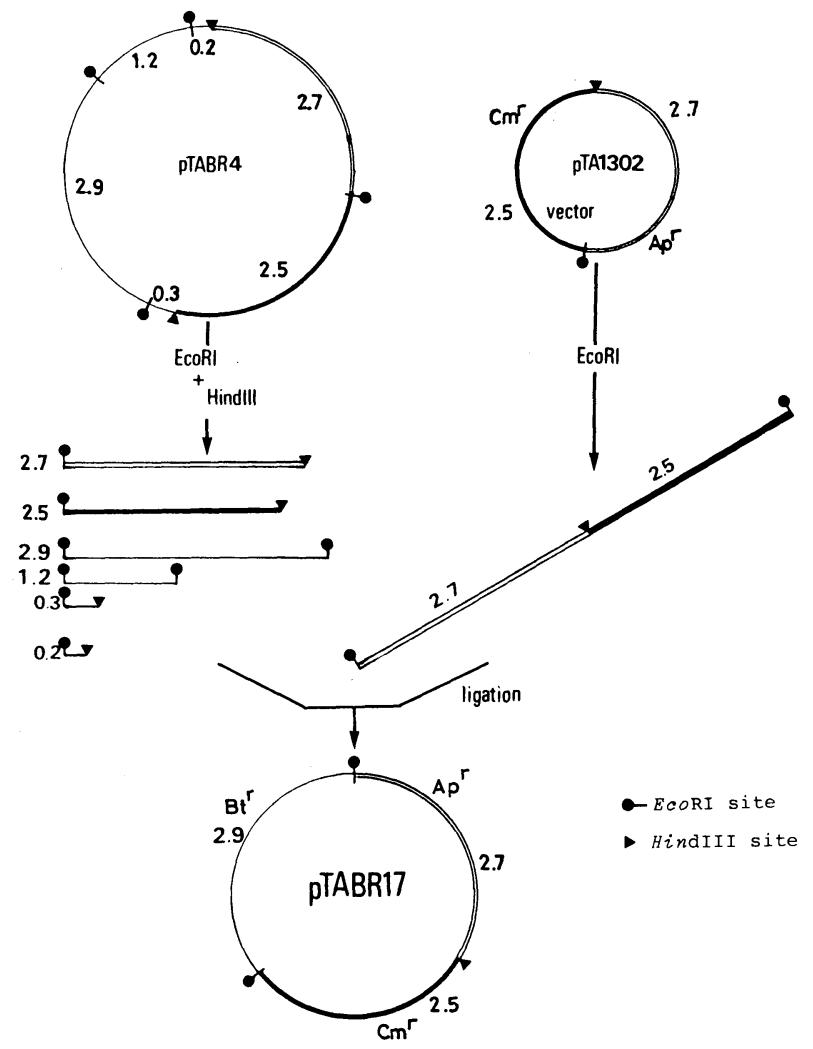

FIG. 4. Schematic Presentation of Construction of pTABR17.

pTABR4 was digested with EcoRI and HindIII to generate six fragments. Vector pTA1302 was digested with $E c o$ RI, and mixed with fragments of EcoRI plus HindIII digested fragments of pTABR4. Only two fragments $(2.9 \mathrm{Md}$ and $1.2 \mathrm{Md}$ ) would be easily cloned into the EcoRI site of pTA1302, because they have two EcoRI

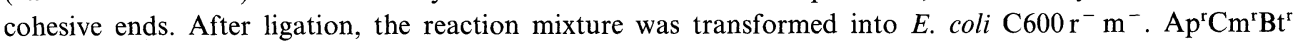
transformants were selected and plasmid DNAs were recovered from them. In this experiment, we obtained only one type of recombinant plasmid which had the $2.9 \mathrm{Md}$ fragment derived from $B$. vitellinus in the EcoRI site of pTA1302. This plasmid was designated as pTABR17. No $\mathrm{Bt}^{\mathrm{r}}$ transformants which had the $1.2 \mathrm{Md}$ fragment were obtained.

B. vitellinus (this is confirmed in the next section). pTABR4 and pTABR10 were composed of only the $4.6 \mathrm{Md} H$ indIII fragment and vector pTA1302. But their orientations were reversed. pTABR5 and pTABR6 contained, in addition to the $4.6 \mathrm{Md}$ fragment, some other HindIII fragments which seemed to have no functions in the butirosin resistance. The butirosin-resistant gene was deduced to be coded on the $4.6 \mathrm{Md}$ fragment, because all the recombinant plasmids contained this fragment. The molecular size of $4.6 \mathrm{Md}$ seemed to be larger than that needed to code a single gene, so we tried to obtain a smaller fragment by subcloning. As shown in Fig. 3, 4.6 Md fragment can be cut by EcoRI into 4 fragments $(2.9,1.2,0.3$ and $0.2 \mathrm{Md})$. To clone 2 large fragments $(2.9$ and $1.2 \mathrm{Md})$ into the EcoRI cutting site of pTA1302, pTABR4 was cut by HindIII and EcoRI and mixed with EcoRI-digested pTA1302, followed by ligation treatment. Competent cells of E. coli $\mathrm{C} 600 \mathrm{r}^{-} \mathrm{m}^{-}$were transformed with the ligation mixture, and $\mathrm{Ap}^{\mathrm{r}} \mathrm{Cm}^{\mathrm{r}} \mathrm{Bt}^{\mathrm{r}}$ transformants were selected. As shown in Fig. 4 (schematic presentation), only the $2.9 \mathrm{Md}$ or $1.2 \mathrm{Md}$ fragment would be easily ligated into the EcoRI site of pTA1302, because they have two EcoRI ends. 


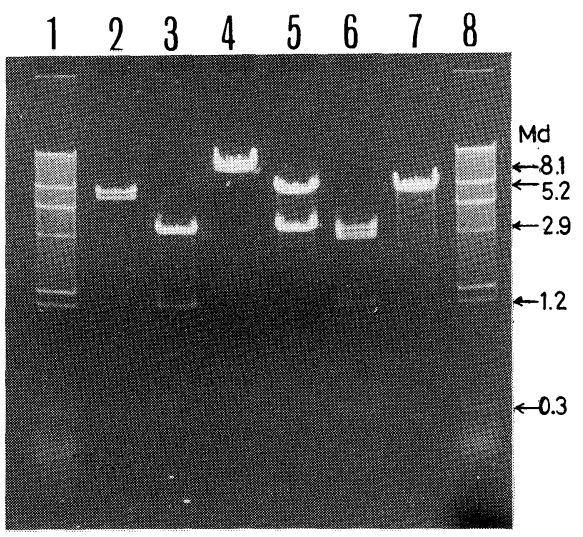

FIG. 5. Cleavage Pattern of pTABR17.

1 and 8, lambda DNA fragments digested with HindIII; 2, pTABR4 digested with HindIII; 3, pTABR4 digested with EcoRI; 4, pTABR 17 digested with HindIII; 5, pTABR17 digested with $E c o$ RI; 6, pTABR4 digested with $E c o$ RI and HindIII; 7, pTA1302 digested with EcoRI. Agarose gel electrophoresis was carried out on $0.7 \%$ agarose slab gel.

In this experiment, we obtained $A p^{r} \mathrm{Cm}^{\mathrm{r}} \mathrm{Bt}^{\mathrm{r}}$ transformants carrying the $2.9 \mathrm{Md}$ fragment but not the $1.2 \mathrm{Md}$ fragment on pTA1302 (Fig. 5). This means that the EcoRI fragment of 2.9 Md codes the gene for resistance to butirosin. The hybrid plasmid containing the $2.9 \mathrm{Md}$ fragment was designated as pTABR 17 (Fig. 4).

Transforming abilities of 5 recombinant plasmids for E. coli $\mathrm{C} 600 \mathrm{r}^{-} \mathrm{m}^{-}$were tested. As shown in Table $I$, the 5 plasmids showed almost the same transforming efficiencies for E. coli. Ratios of $\mathrm{Ap}^{\mathrm{r}} \mathrm{Cm}^{\mathrm{r}} \mathrm{Bt}^{\mathrm{r}}$ transformants to $\mathrm{Ap}^{\mathrm{r}} \mathrm{Cm}^{\mathrm{r}}$ (character of pTA1302) transformants varied among plasmids, but they were all almost one. It was found that these plasmids were able to replicate and express their resistances in E. coli. In fact, plasmid DNAs prepared from these transformants showed the same molecular sizes and the same restriction patterns as the original plasmids used for transformation (data not shown).

B. vitellinus $\mathrm{Z}-1159$, a butirosin producing strain, was known to be resistant not only to butirosin but also to other related aminoglycoside antibiotics, ${ }^{12)}$ because of the substrate specificity of its aminoglycoside-modifying enzyme. So we tested plasmid-carrying $E$. coli as
Table I. Transforming Efficiencies of pTABR Plasmids in E. coli Competent Cells

One microgram of pTABR plasmids was added to $0.5 \mathrm{ml}$ of competent cells $\left(1 \times 10^{8}\right.$ cells $\left./ \mathrm{ml}\right)$ of $E$. coli $\mathrm{C} 600$. DNA uptake was performed at $0^{\circ} \mathrm{C}$ for $30 \mathrm{~min}$ and at $37^{\circ} \mathrm{C}$ for $10 \mathrm{~min}$. $1 \mathrm{ml}$ of $\mathrm{NY}$ medium was added to the competent cell mixture which was then incubated at $37^{\circ} \mathrm{C}$ for $90 \mathrm{~min}$. Transformants were scored on NY plates containing Ap $(50 \mu \mathrm{g} / \mathrm{ml})$ and $\mathrm{Cm}(10 \mu \mathrm{g} / \mathrm{ml})$, and NY plates containing Ap, $\mathrm{Cm}$ and $\mathrm{Bt}(10 \mu \mathrm{g} / \mathrm{ml})$, respectively.

\begin{tabular}{lccc}
\hline \multirow{2}{*}{ Plasmid } & \multicolumn{2}{c}{ Transformants/ml } & $\begin{array}{c}\text { Ratio } \\
\text { (b/a) }\end{array}$ \\
\cline { 2 - 3 } & $\mathrm{Ap}^{\mathrm{r}} \mathrm{Cm}^{\mathrm{r}}(\mathrm{a})$ & $\mathrm{Ap}^{\mathrm{r}} \mathrm{Cm}^{\mathrm{r}} \mathrm{Bt}^{\mathrm{r}}(\mathrm{b})$ & \\
\hline pTABR4 & $1.6 \times 10^{5}$ & $1.3 \times 10^{5}$ & 0.81 \\
pTABR5 & $5.4 \times 10^{4}$ & $2.0 \times 10^{4}$ & 0.37 \\
pTABR6 & $4.6 \times 10^{4}$ & $5.0 \times 10^{4}$ & 1.09 \\
pTABR10 & $5.7 \times 10^{4}$ & $3.3 \times 10^{4}$ & 0.58 \\
pTABR17 & $1.2 \times 10^{5}$ & $8.3 \times 10^{4}$ & 0.69 \\
\hline
\end{tabular}

to the resistance to neomycin $(\mathrm{Nm})$ and kanamycin $(\mathrm{Km})$. E. coli $\mathrm{C} 600 \mathrm{r}^{-} \mathrm{m}^{-}$and E. coli $\mathrm{C} 600 \mathrm{r}^{-} \mathrm{m}^{-}$carrying pTA1302, a vector plasmid, were sensitive to $\mathrm{Bt} ; \mathrm{Km}$ and $\mathrm{Nm}$. E. coli C600 $\mathrm{r}^{-} \mathrm{m}^{-}$carrying pTABR4, pTABR5, pTABR6, pTABR10 and pTABR17, respectively, were all resistant to these 3 antibiotics. It was confirmed that the aminoglycosidemodifying enzyme derived from $B$. vitellinus gene showed the same activity in $E$. coli. This fact is confirmed enzymatically in the last section of this paper.

Southern hybridization analysis of cloned DNAs

In order to confirm that the cloned fragments were really derived from $B$. vitellinus $\mathrm{Z}$ 1159 , hybridization analysis was performed among recombinant plasmids and chromosomal DNA of $B$. vitellinus. Plasmid DNAs of pTA1302, pTABR4, pTABR5, pTABR6 and pTABR 17 were labeled by nick translation and hybridized to HindIII or EcoRI digested chromosomal DNA of $B$. vitellinus. (pTABR10 was not used as a probe because this plasmid was composed of pTA1302 and the same $4.6 \mathrm{Md}$ fragment as pTABR4.) As shown in Fig. 6, all the plasmids except pTA1302 hybridized to the $4.6 \mathrm{Md}$ fragment of $H$ indIII digestion and the $2.9 \mathrm{Md}$ fragment of EcoRI digestion of the B. vitellinus chromo- 


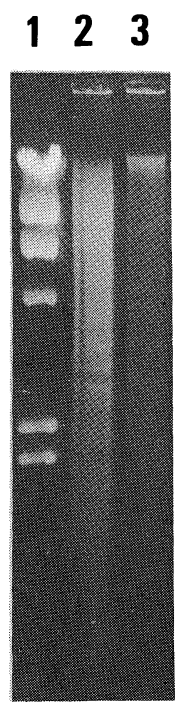

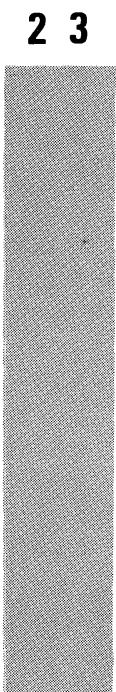

A

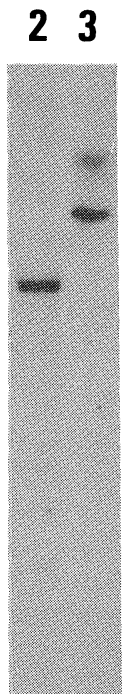

B

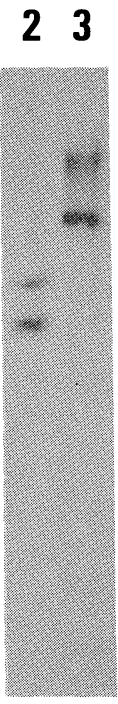

C

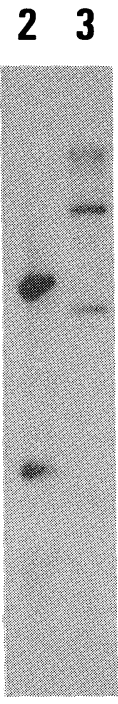

D
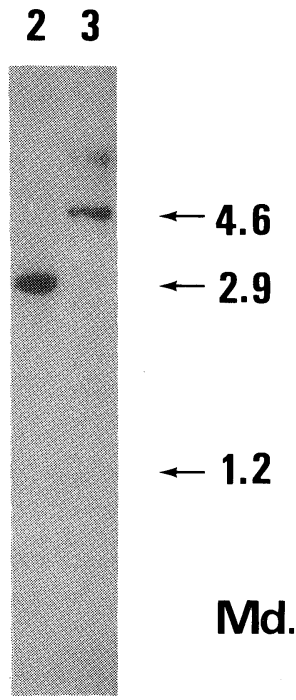

E

FIG. 6. Southern Blot Hybridization Analysis among pTABR Plasmids and Chromosomal DNA of $B$. vitellinus Z-1159.

EcoRI or HindIII digested chromosomal DNA was loaded on a horizontal $0.7 \%$ agarose slab gel. Electrophoresis was performed at $2 \mathrm{~V} / \mathrm{cm}$ for 16 hours in TBE buffer. After alkali denaturation, blotting of DNA fragments onto a nitrocellulose membrane and hybridization procedures were performed as described in Materials AND Methods. 1, lambda-HindIII fragments; 2, EcoRI digested chromosomal DNA of $B$. vitellinus; 3, HindIII digested chromosomal DNA of B. vitellinus. A to E were autoradiographs of Southern blots with ${ }^{32}$ P-labeled pTA1302 (A), pTABR4 (B), pTABR5 (C), pTABR6 (D) and pTABR17 (E).

some in common. pTABR4, pTABR5 and pTABR6 also hybridized to the $1.2 \mathrm{Md}$ fragment of EcoRI digestion in common. This fragment corresponds to the $1.2 \mathrm{Md} E c o \mathrm{RI}$ fragment involved in the $4.6 \mathrm{Md} H$ indIII fragment (see Fig. 3). The 2.3 Md band in lane D3 corresponds to the $2.3 \mathrm{Md}$ HindIII fragment in pTABR6. The 2.2 Md EcoRI band in lane C2 has no direct corresponding band in pTABR5, because a possible corresponding fragment in pTABR5 (the upper $0.3+0.2+0.5 \mathrm{Md}$ fragment or the lower $0.2+0.7 \mathrm{Md}$ fragment in Fig. 3) has already been cut by HindIII and does not have the original EcoRI cutting feature. In case of pTABR17, ${ }^{32}$ p-labeled pTABR 17 only hybridized to $2.9 \mathrm{Md}$ and 4.6 Md fragments because this recombinant plasmid was composed of the vector and $2.9 \mathrm{Md} E c o$ RI fragment. The weak positive hybridization bands corresponding to molecular weights larger than $15 \mathrm{Md}$ in lanes B3,
C3, D3 and E3 might be produced by nonspecific hybridization, because there is much DNA mass at this position as can be seen in lane 3 of the agarose gel. From these results, it was confirmed that pTABR plasmids really contained chromosomal DNA of $B$. vitellinus Z-1159.

Transformation of pTABR plasmids into $B$. subtilis protoplasts

To test expression of the butirosin resistance gene in B. subtilis, five pTABR plasmids were transformed into protoplasts and competent cells of B. subtilis RM125. When competent cells were used as recipients, $\mathrm{Cm}^{\mathrm{r}}$ transformants were obtained at low efficiencies, but $\mathrm{Cm}^{\mathrm{r}} \mathrm{Bt}^{\mathrm{r}}$ transformants were not obtained $\left(\mathrm{Ap}^{\mathrm{r}}\right.$ of pTA1302 is not expressed in B. subtilis). When protoplasts were used as recipients, transformants were obtained as shown in Table II. The number of transformants select- 
Table II. Transforming Efficiencies of pTABR Plasmids in B. subtilis Protoplasts

Protoplasts of $B$. subtilis RM125 were prepared according to the method of Chang and Cohen. ${ }^{9)}$ One microgram of pTABR plasmids was mixed with $0.5 \mathrm{ml}$ of a protoplast suspension (approximately $10^{9}$ protoplasts/ml) and polyethyleneglycol-mediated DNA uptake was performed. Transformants were scored on DM3 regeneration agar plates containing $\mathrm{Cm}(20 \mu \mathrm{g} / \mathrm{ml})$ or both $\mathrm{Cm}(20 \mu \mathrm{g} / \mathrm{ml})$ and $\mathrm{Bt}(50 \mu \mathrm{g} / \mathrm{ml})$. The regeneration efficiency of protoplasts was about $1 \%$ in this experiment.

\begin{tabular}{lcc} 
& \multicolumn{2}{c}{ Transformants/ml } \\
\cline { 2 - 3 } Plasmid & $\mathrm{Cm}^{\mathrm{r}}$ & $\mathrm{Cm}^{\mathrm{r}} \mathrm{Bt}^{\mathrm{r}}$ \\
\hline pTABR4 & 1030 & 646 \\
pTABR5 & 910 & 490 \\
pTABR6 & 270 & 176 \\
pTABR10 & 3000 & 1100 \\
pTABR17 & $3 \times 10^{4}$ & $1 \times 10^{4}$ \\
pTA1302 & $1.8 \times 10^{5}$ & 0 \\
\hline
\end{tabular}

ed by $\mathrm{Cm}^{\mathrm{r}} \mathrm{Bt}^{\mathrm{r}}$ was almost the same as the number of transformants selected by $\mathrm{Cm}^{\mathrm{r}}$ for each plasmid. Cleared lysates were prepared from these transformants and their plasmid DNAs were analyzed by agarose gel electrophoresis. Almost all the plasmids prepared from transformants with 5 pTABR plasmids were somewhat smaller than the original plasmids (data not shown). Only one $\mathrm{Cm}^{\mathrm{r}} \mathrm{Bt}^{\mathrm{r}}$ transformant which had the same size of plasmid DNA as the donor plasmid DNA was obtained on transformation with pTABR10. In order to confirm the stability of the pTABR plasmids in B. subtilis, plasmid DNAs prepared from $\mathrm{Cm}^{\mathrm{r}} \mathrm{Bt}^{\mathrm{r}}$ transformants of B. subtilis were transferred again into $E$. coli $\mathrm{C} 600 \mathrm{r}^{-} \mathrm{m}^{-}$. Plasmid DNAs recovered from the B. subtilis transformants with pTABR5, pTABR6, pTABR 10 and pTABR17 DNAs were able to produce $\mathrm{Ap}^{\mathrm{r}} \mathrm{Cm}^{\mathrm{r}} \mathrm{Bt}^{\mathrm{r}}$ transformants of $E$. coli.
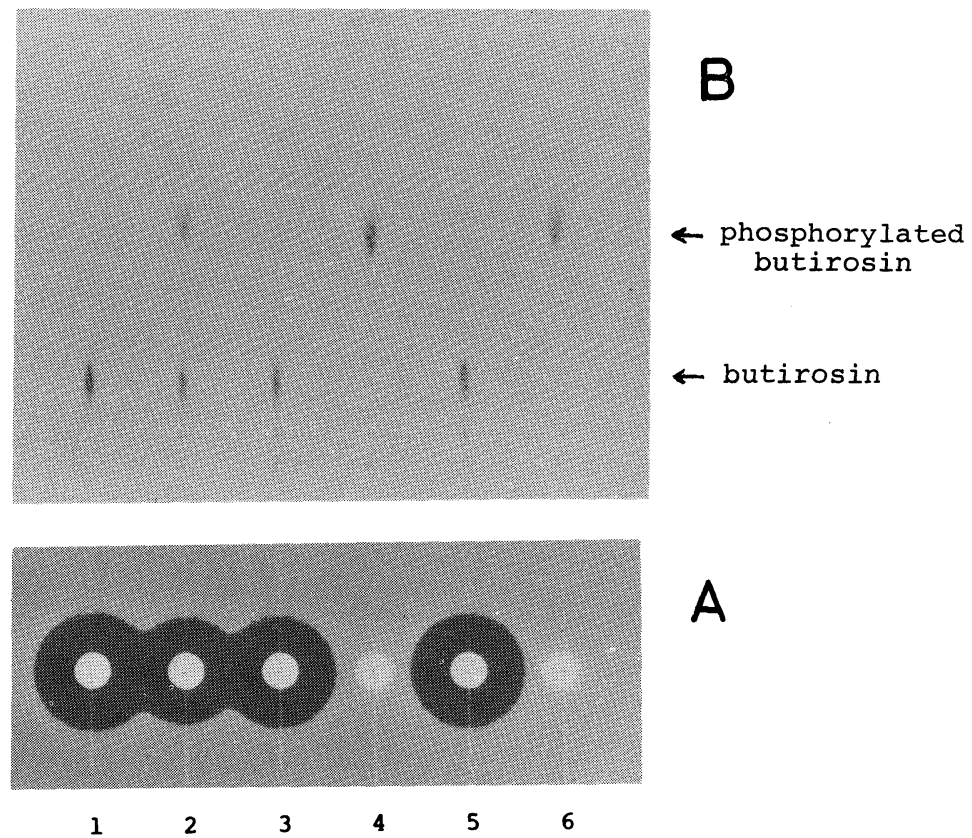

A

FIG. 7. Assay of Aminoglycoside 3'-Phosphotransferase Activity (I).

(A): Cell-free extracts were prepared from $100 \mathrm{ml}$ of late $\log$ phase cultures (approximately $5 \times 10^{8} \mathrm{cells} / \mathrm{ml}$ ) of B. vitellinus Z-1159, B. subtilis RM125, B. subtilis RM125 (pTABR10), E. coli C600 and E. coli C600 (pTABR 10). Reactions were performed in $500 \mu \mathrm{l}$ of $100 \mathrm{~mm}$ phosphate buffer (pH 7.5) containing $20 \mathrm{~mm}$ ATP, $40 \mathrm{~mm} \mathrm{MgSO}{ }_{4} \cdot 7 \mathrm{H}_{2} \mathrm{O}, 4 \mathrm{~mm}$ butirosin and $250 \mu \mathrm{l}$ of cell free extract at $37^{\circ} \mathrm{C}$ for $60 \mathrm{~min}$. Reactions were stopped by heating at $80^{\circ} \mathrm{C}$ for $10 \mathrm{~min}$. After centrifugation supernatants were analyzed for residual butirosin activities on paper discs. The indicator strain used in this experiment was B. subtilis ATCC 6633. (B): Inactivation was also examined by thin-layer chromatography. 1, control (no cell-free extract was added); cell free extract of 2 , B. vitellinus; 3, RM125; 4, RM25 (pTABR10); 5, C600; 6, C600 (pTABR10) was added, respectively. 
But in the case of pTABR4, plasmid DNAs recovered from $B$. subtilis could not transform E. coli to $\mathrm{Ap}^{\mathrm{r}} \mathrm{Cm}^{\mathrm{r}} \mathrm{Bt}^{\mathrm{r}}$ nor $\mathrm{Ap}^{\mathrm{r}} \mathrm{Cm}^{\mathrm{r}}$. Some fragment of the pBR322 portion in the hybrid plasmid pTABR4 which is essential for replication in $E$. coli seems to be lost during replication in B. subtilis.

All the pTABR plasmids recovered from $B$. subtilis except pTABR4 retained replicating abilities in $E$. coli as well as their characteristic resistance genes. However, a small deletion often seemed to have occurred during the replication in $B$. subtilis. Only pTABR 10 retained its original structural integrity without any alteration in size or restriction pattern in B. subtilis.

\section{Assay of aminoglycoside-3'-phosphotransferase} activity

In order to confirm the expression of the $\mathrm{Bt}^{\mathrm{r}}$ gene in both E. coli and B. subtilis, aminoglycoside- $3^{\prime}$-phosphotransferase activities in cell free extracts of $B$. subtilis RM125, B. subtilis RM125 (pTABR10), E. coli C600, E. coli C600 (pTABR10) and butirosinproducing strain $B$. vitellinus Z-1159 were examined. After incubation of butirosin in a reaction mixture containing an excess amount of ATP, the reaction mixture was heated at $80^{\circ} \mathrm{C}$ for $10 \mathrm{~min}$ and remaining butirosin activities were measured on paper discs and by thin layer chromatography. The results are shown in Fig. 7. Butirosin was inactivated by cell free extracts of B. vitellinus, E. coli $\mathrm{C} 600$ (pTABR10) and B. subtilis RM125 (pTABR10). The level of inactivation by the cell free extract of $B$. vitellinus is lower than those by cell free extracts of $E$. coli and $B$. subtilis carrying pTABR 10, respectively. This suggests that butirosin-inactivating enzyme ac-

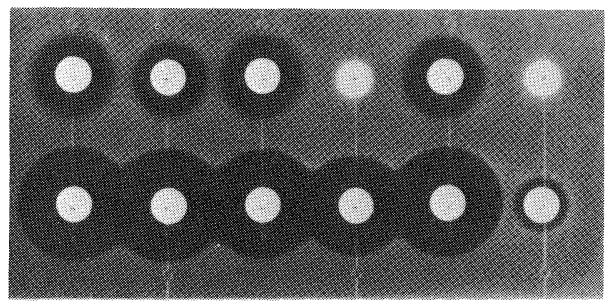

Neomycin

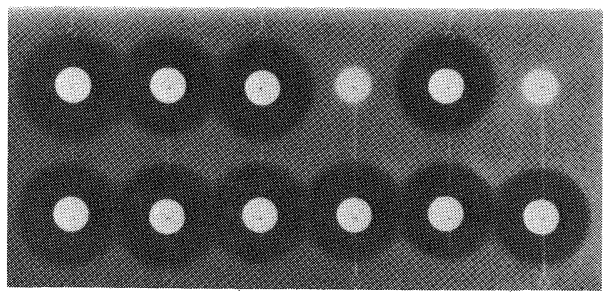

Kanamycin B

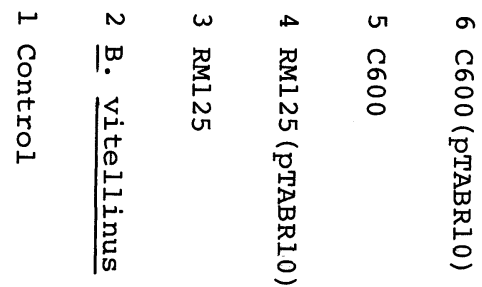

Kanamycin A

Tobramycin

( $3^{\prime}$-deoxy $\mathrm{km} \mathrm{B}$ )

FIG. 8. Assay of Aminoglycoside 3'-Phosphotransferase Activity (II).

Aminoglycoside-inactivating activities in cell-free extracts were measured with neomycin $(\mathrm{Nm})$, kanamycin $\mathrm{A}$ $(\mathrm{Km} \mathrm{A})$, kanamycin B ( Km B) and tobramycin (3'-deoxy $\mathrm{Km} \mathrm{B})$ as substrates. Inactivation was not observed when tobramycin was used as a substrate. This means that the enzymatic inactivating site is the $3^{\prime}$-OH residue of antibiotics. 


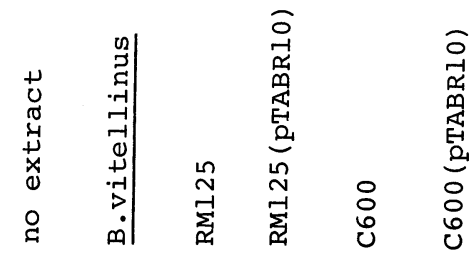

(A)

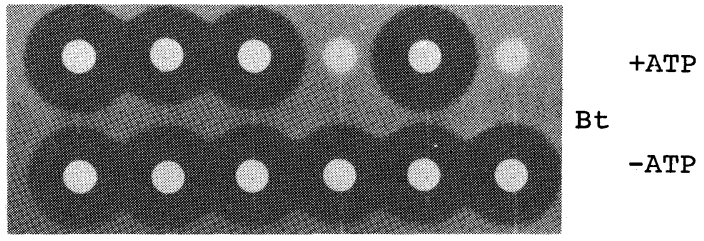

(B)

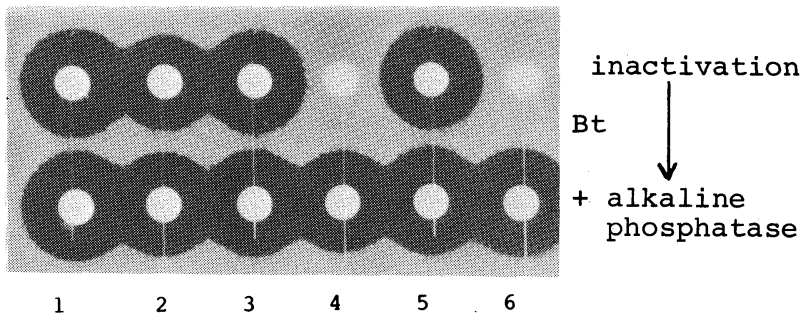

(C)

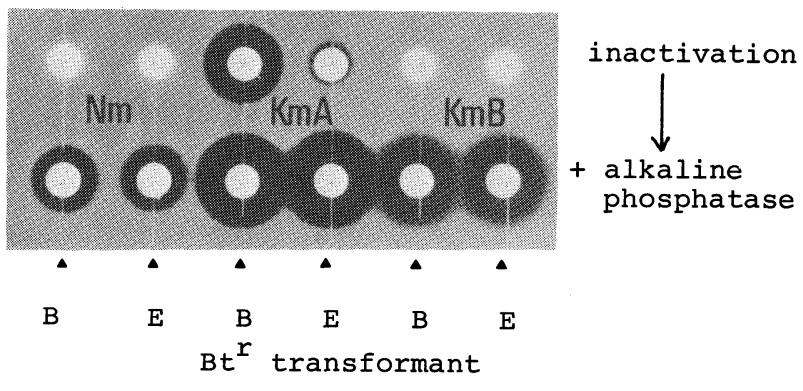

(B: B. subtilis, E: E. coli)

FIG. 9. Confirmation of the Phosphorylation of Aminoglycoside by Cell Free Extracts.

(A) Butirosin was treated with cell free extracts with or without addition of ATP (phosphoryl donor). Inactivation was observed only when ATP was added to the reaction mixture. (B) Inactivated samples of butirosin from the reaction (A) with ATP were treated with bacterial alkaline phosphatase (Boehringer) at $37^{\circ} \mathrm{C}$ for $60 \mathrm{~min}$. The antibiotic activity was recovered with the phosphatase treatment. $(\mathrm{C})$ Neomycin $(\mathrm{Nm})$, kanamycin A ( Km A) or kanamycin B ( Km B) inactivated by cell free extracts of B. subtilis RM125 (pTABR10) or E. coli C600 (pTABR10) was treated with alkaline phosphatase. The treatment restored the antibiotic activities.

tivity in E. coli and B. subtilis increased due to the gene dosage effect.

To confirm phosphorylation of the antibiotics at the $3^{\prime}$-position, several aminoglycoside antibiotics were used as substrates. Figure 8 shows that tobramycin $\left(3^{\prime}\right.$-deoxy kanamycin B) was not inactivated by cell free extracts from B. vitellinus, E. coli (pTABR 10) and B. subtilis (pTABR10). This indicated that the aminoglycoside inactivating enzymes in both E. coli and B. subtilis were modifying 3'$\mathrm{OH}$ residues of aminoglycosides.

Inactivation required ATP and the inactivated aminoglycosides recovered their activities on treatment with bacterial alkaline phosphatase (Fig. 9). These experimental data 
show that recombinant plasmid pTABR 10 really expresses its aminoglycoside- 3 '-phosphotransferase gene from $B$. vitellinus both in E. coli and B. subtilis.

\section{DISCUSSION}

In this paper, we described the cloning and functional expression of the aminoglycoside 3 '-phosphotransferase gene derived from $B$. vitellinus both in E. coli and B. subtilis by using pTA1302 as a vector. This indicates the utility of our plasmid pTA1302 as a shuttle vector in both $E$. coli and B. subtilis. But, in the case of cloning in B. subtilis, deletion of recombinant plasmids was often observed. Similar phenomena of deletion of recombinant plasmids were reported by various researchers (for instance, Kreft et al. ${ }^{14)}$ ). In our case, pTABR10 is stably maintained in $B$. subtilis, but pTABR 4 is not. pTABR4 and pTABR10 are constructed from the same components, pTA4', pBR322' and the $4.6 \mathrm{Md}$ fragment of $B$. vitellinus. The only difference is the orientation of insertion of the $4.6 \mathrm{Md}$ fragment at the HindIII site of pTA1302. If instability of pTABR4 depends on its orientation of insertion, interaction of the DNA sequence between the vector plasmid and donor DNA will play a great role in plasmid instability. Similar results were obtained when we constructed shuttle vector plasmids by in vitro ligation of staphylococcal plasmid pTP4 $\left(\mathrm{Cm}^{\mathrm{r}}, 2.7 \mathrm{Md}\right)$ and pBR322 by HindIII-ligase treatment. One of the shuttle vectors, pTA1312, was not stably maintained in B. subtilis, whereas pTA1311, which had the opposite orientation of ligation compared to pTA1312, was fairly stable.

A butirosin-resistance gene has already been cloned by Courvalin et al. ${ }^{13)}$ from a butirosinproducing bacterium, B. circulans NRRL B3312. But, restriction patterns of the cloned fragments in our experiment were different from those of Courvalin et al.

\section{REFERENCES}

1) S. D. Ehrlich, Proc. Natl. Acad. Sci. U.S.A., 74, 160 (1977).

2) S. D. Ehrlich, Proc. Natl. Acad. Sci. U.S.A., 75, 1433 (1978).

3) T. J. Gryczan and D. Dubnau, Proc. Natl. Acad. Sci. U.S.A., 75, 1428 (1978).

4) T. J. Gryczan, A. G. Shivakumar and D. Dubnau, J. Bacteriol., 141, 246 (1980).

5) T. Hoshino, T. Uozumi and T. Beppu, Agric. Biol. Chem., 44, 2601 (1980).

6) T. Uozumi, T. Hoshino, K. Miwa, S. Horinouchi, T. Beppu and K. Arima, Molec. Gen. Genet., 152, 65 (1977).

7) M. Kono, M. Sasatsu and H. Hamashima, Microbios. Lett., 5, 55 (1978).

8) S. Horinouchi, T. Uozumi, T. Hoshino, A. Ozaki, S. Nakajima, T. Beppu and K. Arima, Molec. Gen. Genet., 157, 175 (1977).

9) S. Chang and S. N. Cohen, Molec. Gen. Genet., 168, 111 (1979).

10) H. Saito and K. Miura, Biochim. Biophys. Acta, 72, 619 (1963).

11) T. Tanaka, M. Kuroda and K. Sakaguchi, $J$. Bacteriol., 129, 1487 (1977).

12) K. Nakahama, H. Shirafuji, I. Nogami, M. Kida and M. Yoneda, Agric. Biol. Chem., 41, 2437 (1977).

13) P. Courvalin, B. Weisblum and J. Davis, Proc. Natl. Acad. Sci. U.S.A., 74, 999 (1977).

14) J. Kreft, J. Parris and W. Goebel, "Genetics of Industrial Microorganisms, 1982" ed. by Y. Ikeda and T. Beppu, Kodansha Ltd., Tokyo, 1983, p. 292. 